\title{
Works Councils and Workplace Health Promotion in Germany
}

\author{
Uwe Jirjahn \\ University of Trier, GLO and IZA \\ Jens Mohrenweiser \\ Bournemouth University \\ Stephen C. Smith \\ George Washington University, GLO and IZA
}

\begin{abstract}
From a theoretical viewpoint, there can be market failures and organizational failures resulting in an underprovision of occupational health and safety. Works councils may help mitigate these failures. Using establishment data from Germany, our empirical analysis confirms that the incidence of a works council is significantly associated with an increased likelihood that the establishment provides more workplace health promotion than required by law. This result also holds in a recursive bivariate probit regression accounting for the possible endogeneity of works council incidence. Furthermore, analyzing potentially moderating factors such as collective bargaining coverage, industry, type of ownership, multi-establishment status and product market competition, we find a positive association between works councils and workplace health promotion for the various types of establishments examined. Finally, we go beyond the mere incidence of workplace health promotion and show that works councils are positively associated with a series of different measures of workplace health promotion.
\end{abstract}

JEL Classification: I18, J28, J50, J81.

Keywords: Non-union employee representation, works council, occupational health and safety, workplace health promotion.

Corresponding Author: Uwe Jirjahn, Universität Trier, Fachbereich IV, Lehrstuhl für Arbeitsmarktökonomik, Universitätsring 15, 54286 Trier, Germany, Email: jirjahn@unitrier.de 


\section{Introduction}

The workplace is undergoing fundamental transformations posing important challenges for the health and safety of employees. Demographic developments involve changes in the composition of the workforce. Specifically, an ageing workforce requires that employers increasingly account for health issues. Moreover, the last decades have witnessed both an intensification of work and an upward trend in work-related health problems (Askenazy and Caroli 2010, Brenner et al. 2004, Cottini and Lucifora 2013, Green 2004, Green and McIntosh 2001). While the computerization of the workplace, the decline of manufacturing jobs, and the growth of service-oriented work have made traditional sources of adverse physical and environmental working conditions less relevant, they have increased the importance of psychosocial job stressors (Capelli et al. 1997).

Work-related health problems involve considerable costs (Pouliakas and Theodossiou 2011). The World Health Organization and the World Bank attribute 3 percent of lost life years to work-related health issues (Kreis and Bodeker 2004). Estimates by the International Labour Organization suggest that work-related diseases and accidents account for economic losses as high as 4 percent of world-wide GDP (ILO 2003). Furthermore, social insurance expenditures on work-related diseases and accidents (e.g., statutory sick pay, disability allowances, industrial injuries disablement and incapacity benefits) account for roughly 2 to 3 percent of GDP in many advanced economies. This exceeds by far what is typically spent on unemployment benefits (Adema and Ladaique 2009). 
Against this background, it is crucial to understand the factors that induce employers to improve workplace health. Our study examines the role of works councils in workplace health promotion (WHP) for Germany. Works councils provide a highly developed mechanism for codetermination at the establishment level. They are a key institution of nonunion employee representation in many West European countries. Compared to their counterparts in most of the other countries, works councils in Germany have acquired quite extensive powers (Jenkins and Blyton 2008).

From a theoretical viewpoint, there exist a series of possible market failures resulting in an underprovision of WHP. Works councils may help mitigate these market failures resulting in an increased provision of WHP. Healthy working conditions have properties of a workplace public good. A works council is a collective voice institution that helps employer and employees to negotiate over the provision of that public good. The works council can also help reduce information asymmetries. It provides employees with better information about unhealthy working conditions and communicates worker preferences to the employer. This allows the employer to implement more effective WHP measures. Moreover, a works council may help overcome commitment problems of the employer. Employees may be not willing to make concessions if they fear that the employer does not undertake promised investments in improving workplace health. The works council can act as a contract enforcer by ensuring that the employer keeps the promises made. This allows to negotiate changes that otherwise cannot be implemented. Finally, codetermination rights increase the bargaining power of the workforce. Increased bargaining power allows the works council to push for a higher level of WHP and, hence, 
to reduce the negative external effects of unhealthy working conditions on employees and society.

Works councils in Germany are mandatory but not automatic. Their creation depends on the initiative of the establishment's workforce. Hence, works councils are not present in all eligible establishments. This allows us to conduct a within-country study by comparing establishments with and without a works council. Using the 2012 wave of the IAB Establishment Panel, our empirical analysis confirms that the incidence of a works council is associated with a higher likelihood that the establishment provides more WHP than required by law. This result holds even when controlling for a rich set of other factors influencing WHP. It also holds in a recursive bivariate probit model that accounts for potential endogeneity of works council incidence. Such endogeneity might result from unobserved factors influencing both the incidence of a works council and the use of WHP.

We also examine whether the relationship between works councils and WHP depends on circumstances and type of firm. Previous research on the productivity effects of works councils has shown that the functioning of establishment-level codetermination can depend on moderating factors (Jirjahn and Smith 2018a). However, usually only one single factor is considered whereby the moderating factor analyzed varies across studies. By contrast, in our study on WHP, we provide a more systematic analysis of moderating factors by performing separate estimates for a series of different types of establishments: establishments with and without collective bargaining status, establishments with and without alternative forms of worker representation, establishments in East and West Germany, foreign-owned and domestically owned establishments, establishments with 
and without owner-managers, establishments in the manufacturing and in the service sector, establishments with and without shift work, establishment belonging and not belonging to multi-establishment firms, and establishments facing different degrees of product market competition. We find a positive relationship between works council incidence and WHP for almost every type of establishment. The relationship appears to be particularly strong in establishments with a foreign owner, establishments located in West Germany and establishments being part of a multi-establishment firm.

Finally, we go beyond the incidence of WHP and examine the role of works councils in a series of detailed WHP measures. We find that works councils impact two broad classes of WHP activities. On the one hand, our results show that works councils are positively associated with measures improving the information flow on work-related health issues. Establishments with a works council have a higher likelihood of using sickness absence analysis, health circles, and employee surveys about health issues. On the other hand, our results show that works councils are positively associated with direct measures to promote workplace health. This holds for measures undertaken within the establishment. Establishments with a works council have a higher likelihood of using inhouse activities (e.g., health checks and physiotherapy) and providing health-related training or advisory service (e.g. regarding mental problems or nutrition issues). It also holds for measures undertaken outside the establishment. Establishments with a works council are more likely to provide financial support to their employees for health promotion activities outside the establishment. Moreover, we find that works council incidence is positively associated with the establishment's participation in cross-company networks on health promotion. 
Economists have shown strong interest in German works councils. This is documented by a rapidly growing literature of econometric studies on the consequences of this institution (Jirjahn and Smith 2018a). The econometric studies have examined the influence of works councils on outcome variables such as wages, personnel turnover, job satisfaction, productivity, profitability, and innovation. Surprisingly, the influence of works councils on WHP has received very little attention. Thus, research on works councils and WHP has so far remained in its infancy.

Hollederer and Wießner (2015) provide an exploratory study that is also based on the IAB Establishment Panel. Their analysis uses a sparse specification including a variable for works council incidence to examine the determinants of the provision of WHP. Hollederer and Wießner confirm that works councils are associated with a higher probability of WHP. However, they do not account for potential endogeneity of works council incidence and do not examine if the effects of works councils are heterogeneous. Moreover, Hollederer and Wießner do not distinguish between different measures of WHP.

Furthermore, our analysis is related to a study by Askildsen et al. (2006). That study examines the relationship between works councils and environmental investments undertaken by establishments. To the extent environmental investments such as investments in purification technologies have a direct influence on the workplace, they can have immediate consequences for workplace health. Using data from manufacturing firms in the 1990s, Askildsen et al.'s study finds that works councils are positively associated with various types of environmental investment such as the introduction of environmentally-friendly production processes or down-the-line technologies. 
On a broader scale, our study is also related to the literature on unions and workplace injuries in Britain and the United States (e.g., Boal 2009, Bryson 2016, Donado 2015, Fenn and Ashby 2004, Reilly et al. 1995, Weil 1999). That literature shows very mixed results on the role of unions in workplace injuries. Our study provides much more than just another data point from a different country. Industrial relations in Germany are characterized by a dual structure of employee representation with both unions and works councils. Works councils provide a highly developed mechanism for nonunion employee representation and, thus, have functions distinct from those of unions. Germany has a system of industrial relations sufficiently different to command attention of the scholars and policy makers interested in employee representation.

The remainder of this paper is organized as follows. The institutional framework is described in Section 2. Section 3 provides the theoretical background discussion. Section 4 presents the data and variables. In Section 5, we discuss the results from the empirical analysis. Section 6 offers our conclusions.

\section{Institutional Framework}

The dual structure of employee representation in Germany involves both works councils and unions (Keller and Kirsch 2015, Mueller-Jentsch 1995, Nienhüser 2014, Silva 2013). Collective bargaining agreements are usually negotiated between unions and employers' associations on a broad industrial level. They regulate wage rates and general aspects of the employment contract. Establishments are covered by a collective bargaining agreement if they are members of an employers' association. These associations function to coordinate member firms during negotiations with unions. The share of establishments covered by firm-level agreements is very small. 
Works councils provide a highly developed mechanism for establishment-level codetermination. Their rights are defined in the Works Constitution Act (WCA), which was introduced in 1952 and amended in 1972, 1989, and 2001. The WCA mandates that works councils be elected by the workforce of establishments with five or more employees. However, while works councils are mandatory, they are not automatic. Their creation depends on the initiative of the establishment's workforce. To introduce a works council, a meeting of the workforce has to be initiated by at least three employees or by a union that has at least one member in the establishment. At this meeting, the electoral board is determined by a majority vote of those who are present. If the meeting fails to elect the electoral board or the meeting has been called for but not held, the labor court appoint a board upon petition. After being established, the electoral board calls the election of the members of the works council, implements the election and announces the results. The cost of the election as well as the cost of operating a works council is borne by the employer.

Works councils are institutionalized bodies of employee representation that have functions that are distinct from those of unions. They are designed to increase joint establishment surplus rather than to redistribute the surplus. The WCA does not allow wage negotiations. Works council and employer are obliged by law to cooperate "in a spirit of mutual trust ... for the good of the employees and of the establishment." The WCA stipulates that they shall collaborate with the serious attempt to reach an agreement and to set aside differences. If council and management fail to reach an agreement, they may appeal to an internal arbitration board or to the labor court. Works councils and employers are not allowed to engage in activities that interfere with the peace within the 
establishment. Specifically, the works council does not have the right to strike and the employer is barred from obstructing the activities of the works council.

Works councils negotiate over a bundle of interrelated establishment policies. On some issues they have the right to information and consultation, on others a veto power over management initiatives, and on others the right to coequal participation in the design and implementation of policy. Their rights are strongest in social and personnel matters such as the introduction of new payment methods, the allocation of working hours and the introduction of technical devices designed to monitor employee performance.

Most importantly in our context, works councils have comprehensive rights in matters of health and safety. They not only have the right to full information and consultation on these matters and monitor that employers comply with the laws on occupational safety and accident prevention. They also have the right of codetermination regarding occupational health and safety. This means that decisions on occupational health and safety matters cannot go against a works council's stated preferences. A works council can even conclude company agreements (Betriebsvereinbarungen) with the employer on these matters.

It is important to note that the behavior of employers and works councils is not completely specified and determined by the letter of the law (Jirjahn and Smith 2006). Thus, the functioning of codetermination cannot be immediately derived from a reading of legislation. In particular, a works council may use its codetermination rights on social and personnel matters to obtain employer concessions on issues where it has no legal powers. For example, the works council may engage in informal wage negotiations with the employer. If employer and works council fail to reach an agreement in these informal 
negotiations, the council can threaten to hinder decisions in areas where its consent is necessary. Moreover, the cooperativeness of the employer can influence the functioning of codetermination. On the one hand, the employer may informally try to hinder the works council even though this is prohibited by law. On the other hand, the employer may choose to involve the works council even in issues that are not covered by the WCA. In the end, only empirical research can reveal the functioning of codetermination in practice.

\section{Theoretical Background}

Employers may to some extent voluntarily invest in WHP in order to reduce sickness absence or personnel turnover and, hence, to increase productivity. If employees prefer a higher level, they may pay for increased WHP through lower wages or higher effort. However, from a theoretical viewpoint, there are a series of possible market failures and organizational failures resulting in an underprovision of WHP. Worker representation has the potential to solve or at least mitigate these failures. As a consequence worker representation should be associated with increased investment in WHP.

\subsection{WHP as a Workplace Public Good}

If employees are willing to tradeoff wages for increased WHP, they could bargain with the employer over wages and improvements in workplace health. However, WHP may have to a larger extent properties of a workplace public good. Each worker may gain from improved working conditions, but this utility is not gained at the expense of any other worker's ability to likewise consume this satisfaction, nor is it easy to exclude workers from the improved working conditions. This implies that there is a free-rider 
problem making the individual-voice mechanism ineffective. That is, employees have little incentive to individually bargain with the employer over WHP (Askildsen et al. 2006, Freeman 1976, Freeman and Medoff 1979, Vanek 1970, Weil 1999). While the individual employee bears the costs of monitoring WHP practices and enforcing changes in these practices, other employees gain from the individually negotiated improvements in working conditions. Therefore, a collective voice institution may in general be necessary to effectively bargain with the employer over WHP measures. A collective voice institution can also reduce transaction costs of firm-level bargaining and helps overcome coordination problems among workers. In Germany, works councils exert this collective voice role.

\subsection{Information Disadvantage of the Employees}

Information asymmetries are a further source of inefficiencies in the provision of WHP. Employees will only demand improvements in workplace health if they are aware of unhealthy working conditions. However, they may suffer from an informational disadvantage relative to the employer with respect to these working conditions (Pouliakas and Thoedossiou 2011). The free rider problem discussed above implies that employees have little incentive to individually gather information about unhealthy working conditions. Employees may also lack the expertise to judge to what extent certain working conditions affect their health. Moreover, the employer may be not willing to voluntarily reveal information about unhealthy working conditions if investment in improved working conditions is costly and there is only a low probability that employees will compensate her for this investment. 
Employee representation can help overcome these difficulties. It offers a solution to the free rider problem and provides economies of scale in the acquisition and processing of information about unhealthy working conditions (Donado and Wälde 2012, Gegax et al. 1991, Nichols et al. 1995, Viscusi 1979, 1983). Moreover, the comprehensive information rights of works councils give employees better access to relevant information about working conditions in the establishment. A works council may even increase the willingness of the employer to reveal such information as it provides an opportunity to negotiate mutually beneficial changes that otherwise would not have been possible. ${ }^{1}$

\subsection{Information Disadvantage of the Employer}

Not only information disadvantages on the employees' side, but also information disadvantages on the employer's side can result in a suboptimal provision of WHP. Even if the employer is interested in improving working conditions to reduce absenteeism or increase employee motivation, she may not be able to provide a suitable improvement if she lacks sufficient information about employees' preferences.

Employees who are not satisfied with the working conditions may 'exit' (i.e., quit). However, the employer does learn little from employees' exit. Exit provides insufficient information on how the firm can improve its personnel policies. The employer may recognize that employees are dissatisfied and that this has negative consequences for retention while the reasons for this remain unclear. This is particularly salient when the preferences of employees who exit differ from the preferences of those who remain with the firm. More generally, Drèze (1976) and Drèze and Hagen (1978) show in a general equilibrium setting that it may be impossible for employees to express 
their preferences via market mechanisms, operating through "hedonic wages". A condition is that the number of preferences be greater than the number of working conditions.

Individual voice is also very likely to provide insufficient information about employees' preferences. The workplace public goods problem discussed above implies that each single employee has to bear the costs of bargaining with the employer while fellow workers gain from improvements in working conditions. Each employee would have to collect data to support his or her views and incur costs of verifying any claims made by the employer. In this context, employees may also face the problem of employer sanctions (e.g., reduced career opportunities or outright dismissal) if expressing their preferences for WHP measures entails that the employer perceives them as excessive users or individuals with a poor health status. ${ }^{2}$ This reduces the incentive to exert individual voice. Moreover, transaction costs and coordination problems may prevent individual voice from being effective. Specifically, without coordination, it is difficult for an individual employee to know the extent to which his or her preferences are shared by other employees. Thus, a collective voice institution may be necessary to aggregate employee preferences and to communicate these preferences to the employer (Askildsen et al. 2006, Freeman 1976, Freeman and Medoff 1979, Heywood and Jirjahn 2009, Smith 1993).

\subsection{The Employer's Commitment Problem}

Commitment problems can also imply that the employer does not provide optimal working conditions (Askildsen et al. 2006, Heywood and Jirjahn 2009, Jirjahn 2009, Freeman and Lazear 1995, Kaufman and Levine 2000, Smith 1991). This is especially 
likely if the employer bargains with each employee and transactions costs prevent the parties from writing an explicit contract for each worker. In this case, employees may anticipate the employer's ex post opportunism. If employees made wage concessions, they may fear that the employer does not undertake the agreed investment in WHP. As a consequence, they are not willing to make such concessions and to bargain over better working conditions. Relatedly, if employees provided information about unhealthy working conditions, they may fear that the employer uses this information against their interests for a restructuring of work entailing job loss. Thus, they tend to refuse sharing their information with the employer.

A works council helps solve the employer's commitment problem. The information rights of the works council allow employees to monitor the employer's behavior and, hence, provide an opportunity to assess the employer's credibility. Moreover, the codetermination rights of the works council protect the interests of the employees and help ensure that promises made about improved working conditions are kept. Thus, the works council can act as a contract enforcer allowing the employer to make promises that would otherwise not be believed. This increases employees' willingness to make concessions to obtain better working conditions.

\subsection{Increased Bargaining Power of Employees}

Codetermination does not only provide a mechanism for negotiating work practices that otherwise cannot be implemented. It also increases employees' bargaining power in those negotiations. A works council may not only use its codetermination rights in matters of occupational health and safety to improve working conditions. The council can also leverage its codetermination rights in other decision areas. The council can threaten to 
withhold consent in another field covered by the WCA (e.g., overtime), in order to obtain employer concessions on WHP. The increased bargaining power allows the works council to push for a higher level of WHP. This may not simply mean a redistribution in favor of employees. It rather can imply an increase in social welfare as the negative external effects of unhealthy working conditions on employees and society are to a larger degree reduced.

\section{Data and Variables}

\subsection{The Data Set}

We draw data from the IAB Establishment Panel of the Institute for Employment Research (Fischer et al. 2009). The IAB Establishment Panel is a representative sample of establishments (with at least one employee covered by social insurance) from all sectors in the German economy. The sample is stratified according to establishment size, industry and federal state. Note that we include variables for the stratification characteristics in the estimations so that we do not need to use weighted regressions (Winship and Radbill 1994).

The IAB is the research institute of the German Federal Employment Agency. The institute contracts with Infratest Sozialforschung, a professional survey and opinion research institute, to conduct the interviews. The data are collected on the basis of a questionnaire and follow-up personal interviews with the owner or top manager of the establishment. ${ }^{3}$ Each year since 1993 (1996), the IAB Establishment Panel has surveyed several thousand establishments in Western (Eastern) Germany. Basic information on the establishment and a core set of questions are asked annually. Additional topics are introduced in specific waves. 
For our analysis we use the 2012 wave of the IAB Establishment Panel. This wave provides detailed information on various measures of WHP. We exclude non-profit organizations and the public sector. Furthermore, as the WCA only applies to establishments with at least five employees, the analysis is restricted to establishments that meet this minimum size.

\subsection{Dependent Variables}

The survey asks: 'Do you use or financially support WHP measures which go beyond the provisions stipulated by law?' The survey lists a series of detailed items. Each of these items can be answered with 'Yes' or 'No'. The items and their descriptive statistics are shown in Table 1. Sickness absence analysis, employee surveys about health issues at the workplace, and health circles are measures to gain systematic information about healthrelated problems within the establishment and to find solutions to these problems. Inhouse activities (e.g., health checks or physiotherapy), and health-related training and advisory service for employees (e.g. concerning mental problems or nutrition) refer to concrete measures improving employees' health. The survey provides also information on whether or not the employer provides financial support to employees for health promotion activities outside the establishment or participates in a cross-company network on health promotion (e.g., a network organized by a health insurance company). Finally there is an item 'other measures'.

In our empirical analysis, we use a general dummy for WHP. This dummy equals 1 if the establishment uses at least one of the measures. 52 percent of the establishments use at least one of the health promotion measures listed in the table. Additionally, we use 
specific dummy variables for the each health promotion measure listed in the table. A dummy is equal to 1 if the establishment uses the respective health promotion measure.

\subsection{Key Explanatory Variable}

The definitions and descriptive statistics of the explanatory variables are shown in Table 2. Our key explanatory variable is a dummy equal to 1 if a works council is present in the establishment. As discussed in Section 2, the creation of a works council depends on the initiative of the establishment's workforce. Thus, works councils are not present in all eligible establishments so we can compare establishments with and without a works council. As suggested by our theoretical background discussion works council should have a positive influence on WHP by facilitating the provision of workplace public goods, solving commitment problems of the employer, improving the information sharing between employer and employees and giving employees more bargaining power.

\subsection{Control Variables}

The data set provides a rich set of control variables. Thus, we can account for a variety of factors that potentially also have an influence on WHP. In order to isolate the role of works councils from other industrial relations factors, we include variables for the coverage by a collective bargaining agreement and for the use of alternative forms of employee representation. Collective bargaining agreements not only regulate wage rates, but also general working conditions. To the extent this also involves WHP, establishments covered by collective bargaining should have a higher likelihood of engaging in WHP. 
Alternative forms of employee representation such as staff spokesmen and round tables are voluntarily implemented by the employer. Similar to works councils, they provide channels for improved communication and information sharing between management and workers. However, they have no legally defined rights and are far less powerful than works councils. Thus, from a theoretical viewpoint, it is an open question if these alternative forms of employee representation can play a role similar to that of works councils.

Employers may to some extent invest in WHP with or without employee representation in order to reduce sickness absence and to improve productivity. The costs and benefits of this investment can depend on series of circumstances. The structure of the workforce may be one factor influencing the tradeoff between the costs and benefits of WHP. In our examination, a series of variables capture the structure of the workforce. The qualification of the workforce is captured by the share of skilled employees and the share of employees with a university degree. If skilled and highly skilled workers are not fit for work, they will not yield a competitive advantage for the establishment. Thus, employers with a skilled or highly skilled workforce should have an increased incentive to invest in the employees' health (Nunez and Prieto 2018). We also include the share of apprentices. Employers often retain apprentices after they have completed their training so young people use the apprenticeship to enter internal labor markets. (Heywood and Jirjahn 2016). Internal labor markets bind employees and firms and may make it particularly profitable to invest in employees' long-term health.

Furthermore, we account for the share of blue-collar workers. Blue-collar workers are directly involved in production and, hence, are exposed to working conditions such as 
noise, vibrations, dangerous machines, and chemical and organic substances that entail increased health risks. Employers may invest in WHP to reduce the resulting sickness absence and, hence, disruptions in production.

Variables for the share of females, part-timers and temporary agency employees are also included. The influence of these variables is ambiguous from a theoretical point of view. On the one hand, they indicate employees with a lower labor force attachment or shorter employment horizon reducing the employer's incentive to invest in the health of these employees. On the other hand, they indicate a high share of peripheral employees ensuring stable employment of primary employees (Heywood and Jirjahn 2009). A stable core workforce increases the employer's willingness to promote workplace health.

Working time issues are captured by the usual weekly hours of full-time employees, flexible working time arrangements, and shift work and Sunday work. There have been concerns that longer working hours entail excessive work contributing to health problems such as irregular heartbeat and, hence, an increased risk of stroke (Kivimäki et al. 2017). Shift work and Sunday work reflect working at unusual times. Specifically, shift work has been shown to cause troublesome health problems such as stress, anxiety, sleeping problems and irritability (Cottini and Lucifora 2013, Finn 1981). Thus, employers using shift work may invest in WHP in order to reduce these problems. Flexible working time arrangement involve two opposing influences. On the one hand, to the extent employees can decide about their starting and finishing times, flexible working time arrangements may contribute to improved work-life balance reducing the need to invest in WHP. On the other hand, these arrangements can involve increased stress and 
health problems if the employer varies starting and finishing times to adjust production to market fluctuations.

The nature of production is accounted for by three dummies for the vintage of production technology and a dummy for innovative activities. Technological change appears to entail an intensification of work as new technologies such as information and communication technologies afford greater facility to management to monitor the pace of work and to determine workflows (Green 2004). Moreover, technological change and innovativeness are accompanied by a reorganization of work toward greater flexibility and multitasking (Campaner et al. 2018, Jirjahn and Mohrenweiser 2019). The reorganization of work additionally contributes to the intensification of work involving an increase in mental health problems (Askenazy and Caroli 2010, Brenner et al. 2004, Cottini and Lucifora 2013). Altogether, this suggests that innovativeness and a technology of a more recent vintage should be associated with an increased incentive to invest in WHP.

Moreover, we account for the managerial environment by including variables for dominant foreign owners and the presence of owner-managers. Employees in foreignowned firms appear to perceive higher job insecurity than employees in domestically owned firms (Dill and Jirjahn 2016, Scheve and Slaughter 2004). Foreign owners may contribute to higher job insecurity as they implement new production processes and management practices in the firm and can more easily shift production to facilities in other countries. The basic point is that perceived job loss fears affect mental health (Burchell 1994). Thus, foreign-owned establishments may have a higher need for investing in WHP than their domestically owned counterparts. 
Owner-managers typically have more personal and informal relationships with their employees. These relationships are often considered by both the owner-manager and the employees as 'like being one big family' (Limborg et al. 2003). The implications for WHP are ambiguous. On the one hand, paternalistic owner-managers may specifically take care of the health of the employees. On the other hand, employees in ownermanaged firms tend to abstain from open criticism (Marlow 2002). This may imply that the owner-manager has less information about employees' preferences and views health issues as being the responsibility of the employees (Hasle et al. 2011).

The legal form of the establishment can also play a role. German law distinguishes between two types of legal forms, namely non-corporate and corporate establishments. Owners of non-corporate firms are fully liable with their entire personal assets whereas owners of corporate firms are only liable up to their individual shares. Owners are more willing to support risky projects if they are protected by limited liability. Thus, to the extent the returns of the investments in WHP are uncertain, these investments are more likely to be undertaken by corporate establishments. The legal form of the establishment is controlled for by a dummy equal to 1 if the establishment is a private limited company or stock corporation.

Moreover, we control for the competitive pressure establishments are facing at their product markets. Building from the literature on competition and innovation (Aghion et al. 2005), one may expect that product market competition involves two opposing influences investments in WHP. On the one hand, product market competition can increase the firm's incentive to undertake such investments to increase its competitiveness. On the other hand, there can be a discouragement effect if high 
competition implies that firms will not succeed even when they undertake the investments.

We also control for establishment size and multi-establishment status. Establishment size should be positively associated with WHP. Implementing WHP may involve a fixed cost, and the fixed cost per employee diminishes with the number of employee receiving WHP. This in turn increases the net benefit of WHP. Similarly, the incentive to invest in WHP should be higher if the fixed cost can be spread across the establishments of a multi-establishment firm. Finally, we also control for industry and location of the establishment by including 12 industry dummies and 15 federal state dummies.

\section{Results}

\subsection{Basic Estimations}

Table 3 shows the basic estimations. The determinants of providing more WHP than required by law are estimated by using the probit procedure. Column (1) shows the initial regression results. A series of control variables take significant coefficients. Larger establishments and establishments that are limited liability companies or stock corporations are more likely to provide WHP. Single-site establishments are less likely to provide WHP. Ownership also plays a role. The presence of an owner-manager emerges as a negative determinant of WHP. Turning to the variables for the structure of the workforce, the shares of apprentices, blue-collar workers and temporary agency workers are positively associated with WHP. The results on technology and innovativeness also conform to expectations. Innovative establishments and establishments with a production technology of a more recent vintage are more likely to provide WHP. Furthermore, 
working time arrangements have an influence. Shift work and flexible working time arrangements are positive determinants of WHP while Sunday work is a negative determinant.

Most salient to our topic, the incidence of a works council is positively associated with the provision of WHP. This conforms to the theoretical expectation that works councils help mitigate market and organizational failures in the provision of workplace health. The positive association is not only statistically significant, but also economically meaningful. Establishments with a works council have a 9.4 percentage point higher probability of providing more WHP than required by law. Given that the mean of the WHP variable equals 52.3 percent, this implies an increase in the probability of WHP provision of 18 percent.

However, not only the works council variable, but also the variable capturing other types of employee representation emerges as a significantly positive determinants of WHP. Alternative forms of nonunion employee representation voluntarily implemented by the employer have a slightly stronger influence than works councils. The use of alternative forms of employee representation is associated with an 11.1 percentage point higher likelihood that the establishment provides WHP. Union employee representation is captured by the variable for collective bargaining coverage. The influence of this type of employee representation is smaller than the influence of a works council. Collective bargaining coverage is associated with a 2.8 percentage point higher probability of providing WHP. The finding that also other types of employee representation are significant determinants of WHP gives rise to the question of whether the influence of these types is simply additive to that of works councils or whether 
collective bargaining coverage and alternative employee representation are complementary or substitutive to works councils. We will address this question when examining if the relationship between works councils and WHP depends on circumstances and type of establishment.

While the positive link between works councils and WHP is consistent with the notion that employee representation helps mitigate market and organizational failures in the provision of workplace health, there may be an alternative interpretation of this link. The link might simply reflect an income effect. A series of studies have shown that the wage level is higher in establishments with a works council (see Jirjahn 2017 for a survey). Thus, if workplace health is a normal good, the influence of works councils on WHP might reflect the higher wage level associated with works council incidence. In order to test this alternative explanation, we include the wage per employee in regression (2). The wage variable takes a significantly positive coefficient. This conforms to the notion that employees earning higher wages demand more workplace health. However most importantly, including the wage variable does not change our key result. Works council incidence remains a significant determinant of WHP and the estimated influence is similar to that obtained by regression (1). Thus, we do not find evidence that the link between works councils and WHP is driven by an income effect. In what follows we do no longer include the wage variable in the regressions as it has a larger number of missing values reducing the number of observations.

We recognize that works council incidence is correlated with establishment size (e.g., Jirjahn and Smith 2006). Very small establishments usually do not have a works council while works councils are present in almost all large establishments. Hence 
following previous studies on works councils, we check the robustness of results by excluding small and large establishments from the analysis. In regression (3), we provide an estimation for medium sized establishments with between 21 to 100 employees. In regression (4), the estimation sample is restricted to establishments with between 21 and 300 employees. Both estimations confirm our key finding. The works council variable takes a significantly positive coefficient and the magnitude of the estimated influence is similar to that obtained for the full estimation sample.

\subsection{Moderating Factors}

A series of previous studies have shown that the consequences of works councils can depend on circumstances and type of establishment. This gives rise to the question of whether the link between works councils and WHP only holds for specific types of establishments or can be considered as rather general. Thus, in what follows, we examine whether moderating factors play a role in the relationship between works councils and WHP. Table 4 provides the results on our key explanatory variable. In order to save space, we suppress the results on the control variables. ${ }^{4}$

Previous research suggests that works councils have a stronger influence on innovativeness, productivity and profitability if establishments are covered by collective bargaining agreements (Huebler and Jirjahn 2003, Jirjahn 2017). These findings fit the hypothesis that, in covered establishments, works councils are less involved in distributional issues and have a stronger focus on performance-enhancing activities. Against this background, we run separate regressions for covered and uncovered establishments. The estimates show a positive influence of works councils on WHP for both types of establishments with the influence being slightly stronger in covered than in 
uncovered establishments. However, the difference in the estimated coefficients is not statistically significant.

Our initial estimations have shown that not only works councils, but also alternative forms of nonunion employee representation voluntarily implemented by employers are positively associated with WHP. This gives rise to the question of whether these alternative forms of nonunion representation are substitutes to mandated works councils. In order to answer this question we perform separate estimations for establishments with and without such alternative forms. The estimations show a positive influence of works councils on WHP for both types of establishments. Interestingly, the positive influence is about twice as large in establishments with the alternative forms of nonunion representation. This suggests that the relationship between alternative forms of nonunion representation and works councils is not substitutive, but quite the contrary complementary. However, the difference in these estimated coefficients is not statistically significant. Thus, we have to conclude that the influences of works councils and alternative forms of nonunion representation appear to be additive. Altogether, the basic point is that our estimates provide no evidence of a substitutive relationship.

The functioning of works councils can depend on whether the establishment is a single-establishment firm or belongs to a multi-establishment firm (Jirjahn 2011). In multi-establishment firms there is a network of works councils coordinated by a central council (Gesamtbetriebsrat) that is composed of delegates from the establishment-level works councils. Thus, the power of an establishment's works council to influence decisions is likely to be stronger if the establishment belongs to a multi-establishment firm. This implies that the link between works councils and WHP should be stronger in 
establishments belonging to a multi-establishment firm. Our estimations conform to this expectation. We find a positive influence of works councils on WHP for both singleestablishment firms and establishments belonging to a multi-establishment firm with the influence being significantly stronger in the latter type of establishment.

Previous research indicates that works councils are less likely to play a trustbuilding and performance-enhancing role in foreign-owned than in domestically owned establishments (Dill and Jirjahn 2017, Heywood and Jirjahn 2014, Jirjahn and Mueller 2014). Against this background one might expect that the link between works councils and WHP should also be weaker in foreign-owned establishments. Our results do not conform to this expectation. While we find a positive link between works councils and WHP for both establishments with foreign owners and establishments with domestic owners, the link is significantly stronger in foreign-owned establishments. One explanation for this finding could be that employees in foreign-owned establishments experience more stressful working conditions including higher perceived job insecurity (Dill and Jirjahn 2016). Thus, works councils in foreign-owned establishments may specialize to a larger extent in activities that improve workplace health.

Owner-managers might play a moderating role, too. Owner-managers appear to be more likely to oppose works councils than hired managers (Jirjahn and Mohrenweiser 2016). This might suggest that works councils might be less effective in promoting workplace health when an owner-manager is present. However, the estimates show no significant difference in the influence of works councils between establishments with owner-managers and establishments with hired managers. 
Furthermore, we provide separate estimates for establishments with and without shift work. Shift work causes troublesome problems for health and on-the-job safety of employees. Works councils can help design shift work schedules that take health issues to a larger degree into account (Jirjahn 2008). Against this background, we examine whether works councils play a specific role in WHP if establishments use shift work. The separate estimates confirm a positive link between works councils and WHP for establishments with and without shift work. They do not indicate that the role of works councils significantly differs between these types of establishments.

Industry and region may also play a moderating role in the functioning of works councils (Frick and Moeller 2003). To examine the role of industry we focus on the manufacturing and the service sector and run separate regressions for the two sectors. The separate regressions confirm a positive link between works councils and WHP for both the manufacturing and the service sector and show no significant difference between the two sectors.

To account for regional differences, we provide separate estimations for establishments in West and East Germany. While these estimations show a positive influence of works councils on WHP for both parts of Germany, the influence is significantly stronger in West Germany. This finding conforms to the notion that workplace partners in West and East Germany do not have the same history so that the functioning of industrial relations to some degree still differs between the two parts of the country (Hyman 1996).

Finally, we examine whether product market competition plays a moderating role to take into account that the economic situation of the establishment can influence the 
functioning of works councils (Jirjahn 2009). With the exception of establishments reporting no competitive pressure, the estimates show a similar influence of works councils on WHP for the various degrees of product market competition. We recognize that the number of establishments facing no competitive pressure is relatively small so that the coefficient on works council incidence is likely to be imprecisely estimated for these establishments.

Altogether, our analysis of potentially moderating influences shows a remarkably robust relationship between works councils and an increased probability of WHP provision for the various types of establishments examined. While the link between works councils and WHP is rather general, it appears to be specifically strong for establishments with foreign owners, establishments belonging to a multi-establishment firm and establishments located in West Germany.

\subsection{Detailed WHP Measures}

So far we have used a broad dichotomous variable for the provision of WHP. At issue is now whether works councils have an influence on specific WHP measures. Thus, in what follows, we analyze the link between works councils and the various WHP measures listed in the survey of the IAB Establishment Panel. Table 5 provides the results on our key explanatory variable.

The estimations show that works councils are associated with various measures improving information exchange on health related issues within the establishment. Establishments with a works council have a significantly higher likelihood of using health circles, sickness absence analysis, and employee surveys on health related questions. A works council can ensure that employees' interests are taken into account 
when employees and employer share information on health related issues. This increases the effectiveness of measures fostering information exchange and, hence, makes their use more likely.

Moreover the estimations provide evidence that works councils are associated with direct measures to promote workplace health. This holds for measures undertaken within the establishment. Establishments with a works council have a significantly higher likelihood of using in-house activities (e.g, health awareness days, health checks and physiotherapy) and providing health-related training and advisory services (e.g., addiction issues, regarding mental problems and nutrition issues). It also holds for measures undertaken outside the establishment. Establishments with a works council are significantly more likely to provide financial support to their employees for health promotion activities outside the establishment. This also supports the notion that works councils foster the use of WHP measures by ensuring that employees' interests are taken into account and providing information that increases the effectiveness of the measures.

Finally, establishments with a works council have a significant higher likelihood of using 'other measures' and participating in cross-company networks on health promotion. Altogether, our regressions suggest that the influence of works councils is not confined to a small set of particular WHP measures. Rather, works council appear to foster a broad range of various WHP measures.

\subsection{The Issue of Endogeneity}

We recognize the possibility that our results might suffer from potential endogeneity of the variable for works council incidence. There might be unobserved factors correlated with both works council incidence and WHP. These unobserved factors could result in an 
omitted variable bias. From a theoretical viewpoint, this bias could result in an overestimation or underestimation of the influence of works councils on WHP. If there were unobserved factors positively influencing both the incidence of a works council and the provision of WHP, the effect of works councils on WHP would be overestimated. For example, unobserved poor working conditions may lead employees to implement a works council and may induce management to provide WHP. In this case, the estimated coefficient on the works council variable would also capture the influence of the unobserved working conditions. By contrast, if there were unobserved factors positively influencing the incidence of a works council and negatively influencing WHP, the effect of works councils on WHP would be underestimated. For example, lazy managers may be not able to build trustful relationships with the workforce leading employees to implement a works council to protect their interests. These lazy managers may also not provide measures to improve workplace health. In that case, the works council variable would also capture the influence of the lazy managers.

In order to examine the possible endogeneity of the works council variable, we return to our broad WHP dummy and estimate a recursive bivariate probit model (Greene 1998, Kassouf and Hoffmann 2006). Let us denote the dummy variable for WHP in establishment $i$ by $y_{1 i}$ and the works council variable by $y_{2 i}$ :

$$
\begin{aligned}
& y_{1 i}=\left\{\begin{array}{c}
1 \text { if } y_{1 i}^{*}>0, \\
0 \text { otherwise }
\end{array}\right. \\
& y_{2 i}=\left\{\begin{array}{c}
1 \text { if } y_{2 i}^{*}>0 \\
0 \text { otherwise }
\end{array}\right.
\end{aligned}
$$

where $y_{1 i}^{*}$ and $y_{2 i}^{*}$ are latent variables. These variables are given by:

$$
y_{1 i}^{*}=\delta y_{2 i}+\boldsymbol{\beta}_{1}^{\prime} \boldsymbol{x}_{1 i}+u_{1 i},
$$




$$
y_{2 i}^{*}=\boldsymbol{\beta}_{2}^{\prime} \boldsymbol{x}_{2 i}+u_{2 i},
$$

where $\delta$ is the coefficient on the works council variable, $\boldsymbol{x}_{1 i}$ and $\boldsymbol{x}_{2 i}$ are the vectors of the other explanatory variables, $\boldsymbol{\beta}_{1}$ and $\boldsymbol{\beta}_{2}$ the corresponding coefficient vectors, and $u_{1 i}$ and $u_{2 i}$ the error terms.

In our context, the coefficients in equation (3) are of primary interest. Assuming that $u_{1 i}$ has a standard normal distribution, the traditional univariate probit procedure estimates $\delta$ and $\boldsymbol{\beta}_{1}$ by maximum likelihood without taking equation (4) into account. Yet, if the works council variable $y_{2 i}$ and the error term $u_{1 i}$ are correlated, the estimate of $\delta$ is biased and inconsistent. Consistent estimates can be obtained by a recursive bivariate probit. Equations (3) and (4) form a simultaneous equations model. This simultaneous model is called recursive as $y_{2 i}$ enters equation (3) while $y_{1 i}$ does not enter equation (4). Equation (4) can be considered as a reduced form equation and (3) as a structural equation. The bivariate probit assumes that the error terms $u_{1 i}$ and $u_{2 i}$ have a bivariate normal distribution with $\mathrm{E}\left[u_{1 i}\right]=\mathrm{E}\left[u_{2 i}\right]=0, \operatorname{Var}\left[u_{1 i}\right]=\operatorname{Var}\left[u_{2 i}\right]=1$, and a correlation $\operatorname{Corr}\left[u_{1 i}, u_{2 i}\right]=\rho$. Equations (3) and (4) are estimated jointly by using full information maximum likelihood.

In principle, identification of the recursive bivariate probit model is ensured by its inherent nonlinearity (Wilde 2000). However, to avoid that identification relies solely on the functional form, exclusion restrictions are usually imposed to improve identification. Finding convincing exclusion restrictions is always a matter of debate so that attempts to account for endogeneity can be largely viewed as exploratory. Here we use the share of establishments with works councils calculated for 41 detailed industrial sectors in 16 federal states. We use the share of establishments with works councils in the year 2009 to 
instrument works council incidence in the individual establishment in the year 2012. The share of establishments with works councils reflects the general propensity within a region and narrowly defined industry that works councils are present. Hence, it should have a positive influence on the individual establishment's probability of having a works council.

Researchers have applied similar aggregation identification strategies in other contexts. Jirjahn and Mueller (2014) use the works council share within industries to instrument works council incidence in productivity regressions. Machin and Wadhwani (1991) use the unionization rate within industries to instrument unionization at the establishment level. Lee (2004) uses the share of government jobs in a locality to instrument public sector employment by workers. Woessmann and West (2006) use average class size within schools as an instrument for actual class size. Cornelissen et al. (2011) use the share of workers receiving performance pay within industries to instrument the individual worker's chance of receiving performance pay.

The validity of the instrument requires that the share of establishments with works councils in the industry and region has no direct effect on the WHP of the individual establishment, but influences WHP only indirectly through the incidence of a works council. Of course, one could imagine that the share of establishments with a works council might reflect industry-specific working conditions that are also present in the individual establishment. This might suggest a direct link between the instrument and the individual establishment's WHP. However, to the extent that our dataset allows to control for relevant working conditions at the establishment level, there should be no direct effect of the instrument. In the regressions, we control among others for innovations, vintage of 
technology, shift work, establishment size, blue collar work, part-time, temporary contracts, skills, apprenticeship, collective bargaining and type of ownership. Moreover, note that our instrument allows us to still include the 12 broadly defined industry dummies and the 15 federal state dummies in the regressions. Altogether, our control variables should capture important aspects of the working conditions within the establishment increasing our confidence in the validity of the instrument. The basic point is that the validity of an instrument can depend on the control variables included (Angrist and Pischke 2009: chapter 4.5.2). An instrument may be not valid per se, but may be valid only after conditioning on covariates. Thus, to the extent that we control for critical establishment characteristics, we do not expect a direct effect of the share of establishments with a works council. We assume that this share influences WHP only indirectly through the incidence of a works council, but not directly and independently of the incidence of the works council.

Table 6 provides the key results of the recursive bivariate probit regression. The determinants of WHP provision are jointly estimated with the determinants of works council incidence. The share of establishments with works councils in the industry and region is a significant determinant of the individual establishment's probability of having a works council. A Wald test only weakly rejects (at the 10 percent significance level) the hypothesis that the incidence of a works council is exogenous. The correlation between the error terms of the WHP equation and the works council equation is negative. This conforms to the notion that, for example, inefficient managers induce employees to implement a works council and do not provide WHP. The negative correlation between the error terms implies that the estimated effect of works councils on WHP in the 
recursive bivariate probit regression is stronger than in the simple probit regressions of Table $3 .^{5}$

Altogether, even when taking the potential endogeneity of works council incidence into account, the estimates confirm our key finding of a positive influence of works councils on WHP. We find only weak evidence of endogeneity of works council incidence with respect to WHP. If anything, the evidence suggests that possible endogeneity implies that the positive effect of works councils on WHP provision is underestimated in the simple probit regressions.

\section{Conclusions}

From a theoretical point of view, there exist a series of possible market and organizational failures resulting in an underprovision of WHP. Works councils may help overcome or at least mitigate these failures resulting in an increased use of WHP within establishments. Based on German data from the IAB Establishment Panel, our empirical analysis confirms that establishments with a works council have a higher likelihood of providing more WHP than required by law. This result also holds when accounting for the potential endogeneity of the incidence of a works council.

Furthermore, our analysis shows that the link between works councils and WHP is rather general and holds for various circumstances and types of establishments. However, the strength of the link appears to depend on the type of establishment. It is particularly strong for establishments located in West Germany, foreign-owned establishments, and establishments being part of a multi-establishment firm. Moreover, we find that the influence of works councils is not confined to specific measures, but rather applies to a broad range of various WHP measures. 
Our estimates also suggest that not only works councils, but also union employee representation and alternative forms of nonunion representation voluntarily implemented by employers have a positive influence on WHP. However, these types of employee representation do not appear to be substitutes to works councils. The influences of works councils and the other types of employee representation appear to be simply additive.

We end this study with recommendations for future research. First, it would be interesting to extend our analysis for Germany to other countries. This would be particularly interesting as issues of occupational health and safety play an important role in works council legislation in many other countries (Jirjahn and Smith 2018b). Second, now that the role of works councils in the use of WHP has been examined in detail, it would be interesting to analyze whether works councils also have an influence on the outcomes of WHP measures. This applies to both the economic performance of establishments and the health and wellbeing of employees. 


\section{References}

Adema, W. and M. Ladaique. 2009. "How Expensive Is the Welfare State? Gross and Net Indicators in the OECD Social Expenditure Database (SOCX)," OECD Social, Employment and Migration Working Papers 92, OECD.

Aghion, P., Bloom, N., Blundell, R., Griffith, R. and Howitt, P. 2005. "Competition and Innovation: an Inverted-U Relationship,” Quarterly Journal of Economics 120: 701-728.

Aghion, Philippe and Benjamin Hermalin. 1990. "Legal Restrictions on Private Contracts Can Enhance Efficiency," Journal of Law, Economics and Organization 6: 381 - 409.

Angrist, Joshua D. and Jörn-Steffen Pischke. 2009. Mostly Harmless Econometrics. Princeton University Press. Princeton and Oxford.

Askenazy, Philippe and Eve Caroli. 2010. "Innovative Work Practices, Information Technologies, and Working Conditions: Evidence for France," Industrial Relations 49: 544 -565 .

Askildsen, Jan Erik, Uwe Jirjahn and Stephen C. Smith. 2006. "Works Councils and Environmental Investment: Theory and Evidence from German Panel Data," Journal of Economic Behavior and Organization 60: 346 - 372.

Boal, William M. 2009. "The Effect of Unionism on Accidents in U.S. Coal Mining, 19871929," Industrial Relations 48: 97-120.

Brenner, Mark D., David Fairris and John Ruser. 2004. "Flexible Work Practices and Occupational Safety and Health: Exploring the Relationship Between Cumulative Trauma Disorders and Workplace Transformation," Industrial Relations 43: 242 - 266.

Bryson, Alex. 2016. "Health and Safety Risks in Britain's Workplaces: Where Are They and Who Controls Them?" IZA Discussion Paper No. 9770, Bonn.

Burchell, B. 1994. "The Effects of Labour Market Position, Job Insecurity and Unemployment on Psychological Health," in D. Gallie, C. Marsh and C. Vogler, eds., Social Change and the Experience of Unemployment, Oxford University Press, Oxford: 188 - 212.

Campaner, Annika, John S. Heywood and Uwe Jirjahn. 2018. "Flexible Work Organization and Employer Provided Training: Evidence from German Linked Employer-Employee Data," IZA Discussion Paper No. 11696, Bonn.

Capelli, Peter, Laurie Bassi, Harry Katz, David Knoke, Paul Osterman and Michael Useem. 1997. Change at Work, Oxford University Press, New York.

Card, David. 1995. "Earnings, Schooling and Ability Revisited," Research in Labor Economics 14, pp. 23-48.

Cornelissen, Thomas, John S. Heywood and Uwe Jirjahn. 2011. "Performance Pay, Risk Attitudes and Job Satisfaction," Labour Economics 18: 229 - 239. 
Cottini, Elena and Claudio Lucifora. 2013. "Mental Health and Working Conditions in Europe," Industrial and Labor Relations Review 66: 958 - 988.

Dill, Verena and Uwe Jirjahn. 2016. "Foreign Owners and Perceived Job Insecurity: Evidence from Linked Employer-Employee Data," International Journal of Manpower 37: 1286 1303.

Dill, Verena and Uwe Jirjahn. 2017. "Foreign Owners and the Quality of Industrial Relations in Germany," Economic and Industrial Democracy 38: 5 - 25.

Donado, Alejandro. 2015. "Why Do Unionized Workers Have More Nonfatal Occupational Injuries?” Industrial and Labor Relations Review 68: 153 - 183.

Donado, Alejandro and Klaus Wälde. 2012. "How Trade Unions Increase Welfare," Economic Journal 122: 1 - 20.

Drèze, Jacques. 1976. "Some Theory of Labor Management and Participation," Econometrica 44: $1125-1140$.

Drèze, Jacques and Kare P. Hagen. 1978. "Choice of Product Quality: Equilibrium and Efficiency," Econometrica 46: 493 - 513

Fenn, Paul and Simon Ashby. 2004. "Workplace Risk, Establishment Size and Union Density," British Journal of Industrial Relations 42: 461 - 480.

Finn, P. 1981. "The Effects of Shift Work on the Lives of Employees," Monthly Labor Review 104: $31-35$.

Fischer, Gabriele, Florian Janik, Dana Mueller and Alexandra Schmucker. 2009. "The IAB Establishment Panel - Things Users Should Know," Schmollers Jahrbuch - Journal of Applied Social Science Studies 129: 133 - 48.

Freeman, Richard B. 1976. "Individual Mobility and Union Voice in the Labor Market," American Economic Review 66: 361 - 377.

Freeman, Richard B. and Edward P. Lazear. 1995. "An Economic Analysis of Works Councils," in Works Councils - Consultation, Representation and Cooperation in Industrial Relations, edited by Joel Rogers and Wolfgang Streeck, Chicago: University of Chicago Press: 27 - 52.

Freeman, Richard B. and James L. Medoff. 1979. "The Two Faces of Unionism," The Public Interest 57: $69-93$.

Frick, Bernd and Iris Moeller. 2003. "Mandated Works Councils and Firm Performance: Labor Productivity and Personnel Turnover in German Establishments," Journal of Applied Social Science Studies 123: 423 - 454.

Gegax, D., S. Gerking and W. Schulze. 1991. "Perceived Risk and the Marginal Value of Safety," Review of Economics and Statistics 70: 589 - 596.

Green, Francis. 2004. "Why Has Work Become More Intense?” Industrial Relations 43: 709 741. 
Green, Francis and Steven McIntosh. 2001. "The Intensification of Work in Europe," Labour Economics 8: 291 - 308.

Greene, W. H. 1998. "Gender Economics Courses in Liberal Arts Colleges: Further Results," Journal of Economic Education 29: 291 - 300.

Hasele, P., H.J. Limborg, T. Kallehave, C. Klitgaard and T.R. Andersen. 2011. "The Working Environment in Small Firms: Responses from Owner-Managers," International Small Business Journal 30: 622 - 639.

Heywood, John S. and Uwe Jirjahn. 2002. "Payment Schemes and Gender in Germany," Industrial and Labor Relations Review 56: 44 - 64.

Heywood, John S. and Uwe Jirjahn. 2009. "Family Friendly Practices and Worker Representation: German Evidence," Industrial Relations 48: 121 - 145.

Heywood, John S. and Uwe Jirjahn. 2014. "Variable Pay, Industrial Relations and Foreign Ownership: Evidence from Germany," British Journal of Industrial Relations 52: 521 552.

Heywood, John S. and Uwe Jirjahn. 2016. "The Hiring and Employment of Older Workers in Germany: A Comparative Perspective," Journal for Labour Market Research 49: 349 366.

Hollederer, Alfons and Frank Wießner. 2015. "Prevalence and Development of Workplace Health Promotion in Germany: Results of the IAB Establishment Panel 2012," International Archives of Occupational and Environmental Health 88: 861 - 873.

Huebler, Olaf and Uwe Jirjahn. 2003. "Works Councils and Collective Bargaining in Germany: The Impact on Productivity and Wages," Scottish Journal of Political Economy 50: 1-21.

Hyman, Richard. 1996. "Institutional Transfer: Industrial Relations in Eastern Germany," Work Employment and Society 10: $601-639$.

Ichino, Andrea and Rudolf Winter-Ebmer. 1999. "Lower and Upper Bounds of Returns to Schooling: An Exercise in IV Estimation with Different Instruments," European Economic Review 43, pp. 889-901.

ILO 2003. Safety Culture at Work. Safety in Numbers - Pointers for a Global Safety Culture at Work, Geneva: International Labour Office.

Jenkins, J. and P. Blyton. 2008. "Works Councils," in P. Blyton, N. Bacon, J. Fiorito and E. Heery, eds., The Sage Handbook of Industrial Relations, London: Sage, 346 - 357.

Jirjahn, Uwe. 2008. "On the Determinants of Shift Work and Overtime Work: Evidence from German Establishment Data," British Journal of Industrial Relations 46: 133 - 168.

Jirjahn, Uwe. 2009. "The Introduction of Works Councils in German Establishments: Rent Seeking or Rent Protection?" British Journal of Industrial Relations 47: 521 - 545. 
Jirjahn, Uwe. 2012. "Nonunion Worker Representation and the Closure of Establishments: German Evidence on the Role of Moderating Factors," Economic and Industrial Democracy 33: $4-26$.

Jirjahn, Uwe. 2017. "Works Councils and Collective Bargaining in Germany: A Simple Theoretical Extension to Reconcile Conflicting Empirical Findings," Journal of Institutional and Theoretical Economics 173: 322 - 346.

Jirjahn, Uwe. 2018. "Works Councils and Employer Attitudes toward HRM Practices," Journal of Participation and Employee Ownership 1: 98 - 127.

Jirjahn, Uwe and Kornelius Kraft. 2011. "Do Spillovers Stimulate Incremental or Drastic Product Innovations? Evidence from German Establishment Data," Oxford Bulletin of Economics and Statistics 73: $509-538$.

Jirjahn, Uwe and Jens Mohrenweiser 2016. "Owner-Managers and the Failure of Newly Adopted Works Councils," British Journal of Industrial Relations 54: 815 - 845.

Jirjahn, Uwe and Jens Mohrenweiser. 2019. "Performance Pay and Applicant Screening," British Journal of Industrial Relations 57: 540 - 575.

Jirjahn, Uwe and Steffen Mueller. 2014. "Nonunion Worker Representation, Foreign Owners and Firm Performance," Oxford Economic Papers 66: 140 - 163.

Jirjahn, Uwe and Stephen C. Smith. 2006. "What Factors Lead to Management to Support or Oppose Employee Participation - with and without Works Councils? Hypotheses and Evidence from Germany," Industrial Relations 45: 650 - 680.

Jirjahn, Uwe and Stephen C. Smith. 2018a. "Nonunion Employee Representation: Theory and the German Experience with Mandated Works Councils," Annals of Public and Cooperative Economics 89: $201-234$.

Jirjahn, Uwe and Stephen C. Smith. 2018b. "Works Councils and Employee Board Representation: Cross-National Comparative Practices and Determinants," Working Paper, George Washington University, Washington.

Kassouf A. L. and R. Hoffman. 2006. "Work-Related Injuries Involving Children and Adolescents: Application of a Recursive Bivariate Probit Model," Brazilian Review of Econometrics 26: 105 - 126.

Kaufman, Bruce E. and David I. Levine. 2000. "An Economic Analysis of Employee Representation," in Nonunion Employee Representation: History, Contemporary Practice, and Policy, edited by Bruce E. Kaufman and David I. Levine, New York: M.E. Sharpe: 149 -175 .

Keller, Berndt and Anja Kirsch. 2015. "Employment Relations in Germany," in G. Bamber, R.D. Lansbury, N. Wailes and C.F. Wright, eds., International and Comparative Employment Relations: National Regulation and Global Changes, $6^{\text {th }}$ edition, London, Sage: $179-207$.

Kivimäki, Mika et al. 2017. "Long Working Hours as a Risk Factor for Atrial Fibrillation: A Multi-Cohort Study,” European Heart Journal 38: 2621 - 2628. 
Kreis, J. and W. Bodeker. 2004. Indicators of Work-Related Health Monitoring in Europe, Wirtschaftsverlag NW, Bremerhaven.

Lee, S. 2004. "A Re-examination of Public Sector Wage Differentials in the United States: Evidence from the NLSY with Geocode," Industrial Relations 43: 448 - 472.

Limborg, H.J., H. Hvnegaard, E. Thoft, T. Kierbyholm, E.L. Christensen and and C.T. Aside. 2003. One Big Family - Making the Small Business an Attractive Workplace. Brussels: European Agency of Safety and Health.

Machin, S. and S. Wadhwani. 1991. "The Effects of Unions on Organizational Change and Employment,” Economic Journal 101: 835 - 854.

Marlow, S. 2002. "Regulating Labour Management in Small Firms," Human Resource Management Journal 12: 25 - 43.

Mueller-Jentsch, Walther 1995. "Germany: From Collective Voice to Co-Management," in Joel Rogers and Wolfgang Streeck, eds., Works Councils - Consultation, Representation and Cooperation in Industrial Relations, Chicago: University of Chicago Press: 53 - 78.

Nicols, T., A. Dennis and W. Guy. 1995. "Size of Employment Unit and Injury Rates in British Manufacturing: A Secondary Analysis of WIRS 1990 Data," Industrial Relations Journal 26: $45-56$.

Nienhüser, Werner. 2014. "Works Councils," in Adrian Wilkinson, Jimmy Donaghey, Tony Dundon and Richard B. Freeman, eds., Handbook on Research on Employee Voice, Cheltenham, Edward Elgar Press: 247-263.

Nunez, Imanol and Maite Prieto. 2018. "The Effect of Human Capital on Occupational Health and Safety Investment: An Empirical Analysis of Spanish Firms," Human Resource Management Journal, Forthcoming.

Pouliakas, Konstantions and Ioannis Theodossiou. 2011. "The Economics of Health and Safety at Work: An Interdisciplinary Review of the Theory and Policy," Journal of Economic Surveys 25: $1-52$.

Reily, Barry, Pierella Paci and Peter Holl. 1995. "Unions, Safety Committees and Workplace Injuries," British Journal of Industrial Relations 33: 275 - 288.

Scheve, Kenneth and Matthew J. Slaughter. 2004. "Economic Insecurity and the Globalization of Production," American Journal of Political Science 48: 662 - 674.

Silva, Stephen J. 2013. Holding the Shop Together-German Industrial Relations in the Postwar Era. Cornell University Press, Ithaca and London.

Smith, Stephen C. 1991. "On the Economic Rationale for Codetermination Law," Journal of Economic Behavior and Organization 16: 261 - 281. 
Smith, Stephen C. 1993. "Worker Participation and Workplace Public Goods: Some Theory and Attitudinal Evidence from U.S. Labor-Managed and Codetermined Firms," in S. Mahalingham et. al., eds., Labour Participatory Economy, Mittal: 69 - 93.

Vanek, Jaroslav, 1970. The General Theory of Labor-Managed Market Economies. Cornell University Press, Ithaca, NY.

Viscusi, W. 1979. Employment Hazards: An Investigation of Market Performance, Cambridge, Mass.: Harvard University Press.

Viscusi, W. 1983. Risk by Choice: Regulating Health and Safety in the Workplace, Cambridge, Mass.: Harvard University Press.

Weil, David. 1999. "Are Mandated Health and Safety Committees Substitutes for or Supplements to Labor Unions?” Industrial and Labor Relations Review 52: 339 - 360.

Wilde, J. 2000. "Identification of Multiple Probit Models with Endogenous Dummy Regressors," Economics Letters 69: 309 - 312.

Winship, C. and L. Radbil. 1994. "Sampling Weights and Regression Analysis," Sociological Methods and Research 23: 230 - 257.

Woessmann, L. and M. West. 2006. "Class Size Effects in School Systems around the World: Evidence from Between-Grade Variation in TIMMS," European Economic Review 50: 695 $-736$. 
Tables

Table 1: Definitions and Descriptive Statistics of Dependent Variables

\begin{tabular}{|l|l|c|}
\hline Variable & Definition & Mean \\
\hline Sickness absence analysis & $\begin{array}{l}\text { Dummy variable equals 1 if the establishment uses analysis of sickness } \\
\text { absence }\end{array}$ & 0.335 \\
\hline Employee surveys & $\begin{array}{l}\text { Dummy variable equals 1 if the establishment uses employee surveys } \\
\text { about health issues at workplace }\end{array}$ & 0.239 \\
\hline Health circles & $\begin{array}{l}\text { Dummy variable equals 1 if there are discussion groups on health } \\
\text { problems in the establishment }\end{array}$ & 0.129 \\
\hline In-house activities & $\begin{array}{l}\text { Dummy variable equals 1 if the establishment provides in-house } \\
\text { activities (e.g., organization of active breaks, establishment sports } \\
\text { activities, health awareness days, health checks, physiotherapy) }\end{array}$ & 0.203 \\
\hline Health training & $\begin{array}{l}\text { Dummy variable equals 1 if the establishment provides training or } \\
\text { advisory service for employees (e.g., concerning addiction issues, } \\
\text { mental problems or nutrition issues) }\end{array}$ & 0.162 \\
\hline Financial support & $\begin{array}{l}\text { Dummy variable equals 1 if the establishment provides financial } \\
\text { support for health promotion activities outside the establishment }\end{array}$ & 0.097 \\
\hline Cross-company network & $\begin{array}{l}\text { Dummy variable equals 1 if the establishment participates in a cross- } \\
\text { company network on health promotion (e.g., cooperation with health } \\
\text { insurance companies) }\end{array}$ & $\begin{array}{l}0.125 \\
\text { promote workplace health }\end{array}$ \\
\hline Other measures & $\begin{array}{l}\text { Dummy variable equals 1 if the establishment uses of at least one of } \\
\text { the measures listed above }\end{array}$ & 0.523 \\
\hline
\end{tabular}

$\mathrm{N}=8215$. Use of multiple measures of workplace health promotion is possible. 
Table 2: Definitions and Descriptive Statistics of Explanatory Variables

\begin{tabular}{|c|c|}
\hline Variable & Definition (Mean, Standard Deviation) \\
\hline Works council & Dummy variable equals 1 if the establishment has a works council $(0.257,0.437)$ \\
\hline Other representation & $\begin{array}{l}\text { Dummy variable equals } 1 \text { if the establishment has implemented alternative forms of employee } \\
\text { representation such as staff spokesmen or round tables }(0.122,0.327)\end{array}$ \\
\hline Collective bargaining & $\begin{array}{l}\text { Dummy variable equals } 1 \text { if the establishment is covered by a collective bargaining agreement } \\
(0.400,0.490)\end{array}$ \\
\hline $\operatorname{Ln}($ size $)$ & Log of number of employees $(3.477,1.432)$ \\
\hline University degree & Share of the workforce with a university degree $(0.086,0.164)$ \\
\hline Skilled employees & Share of the workforce with completed apprenticeship training $(0.683,0.265)$ \\
\hline Apprentices & Apprentices as a share of the workforce $(0.044,0.078)$ \\
\hline Women & Share of the workforce that is female $(0.395,0.293)$ \\
\hline Part-time employees & Share of the workforce that is part-time $(0.233,0.257)$ \\
\hline Blue-collar workers & Blue-collar workers as a share of the workforce $(0.774,0.219)$ \\
\hline Temporary agency & Temporary agency employees as a share of the workforce $(0.022,0.079)$ \\
\hline Weekly hours & $\begin{array}{l}\text { Usual weekly hours for full-time employees in the establishment excluding overtime hours } \\
(39.26,1.804)\end{array}$ \\
\hline Flextime & $\begin{array}{l}\text { Dummy variable equals } 1 \text { if the establishment has flexible working time arrangement for its } \\
\text { employees }(0.373,0.484)\end{array}$ \\
\hline Shift work & Dummy variable equals 1 if the establishment has shift work $(0.371,0.483)$ \\
\hline Sunday work & Dummy variable equals 1 if the establishment is open for business on Sundays $(0.191,0.393)$ \\
\hline Satisfactory technology & $\begin{array}{l}\text { Dummy variable equals } 1 \text { if the establishment uses a satisfactory production technology, zero } \\
\text { otherwise }(0.290,0.454)\end{array}$ \\
\hline Modern technology & $\begin{array}{l}\text { Dummy variable equals } 1 \text { if the establishment uses a modern production technology, but not the } \\
\text { latest one }(0.493,0.500)\end{array}$ \\
\hline Latest technology & $\begin{array}{l}\text { Dummy variable equals } 1 \text { if the establishment uses the latest production technology }(0.181 \text {, } \\
0.385)\end{array}$ \\
\hline Innovation & $\begin{array}{l}\text { Dummy variable equals } 1 \text { if the establishment launched a product innovation or implemented a } \\
\text { process innovation in the previous two years }(0.523,0.499)\end{array}$ \\
\hline Limited liability & $\begin{array}{l}\text { Dummy variable equals } 1 \text { if the establishment is a private limited company or stock corporation } \\
(0.711,0.453)\end{array}$ \\
\hline Single-site & $\begin{array}{l}\text { Dummy variable equals } 1 \text { if the establishment has no subsidiaries and is not itself a subsidiary } \\
(0.739,0.439)\end{array}$ \\
\hline Foreign owner & Dummy variable equals 1 if the establishment has a dominant foreign owner $(0.076,0.266)$ \\
\hline Owner-manager & Dummy variable equals 1 if the establishment is managed by its owner $(0.707,0.455)$ \\
\hline Minor pressure & Dummy variable equals 1 if the establishment reports minor competitive pressure $(0.119,0.324)$ \\
\hline Medium pressure & $\begin{array}{l}\text { Dummy variable equals } 1 \text { if the establishment reports medium competitive pressure }(0.416 \text {; } \\
0.493)\end{array}$ \\
\hline High pressure & Dummy variable equals 1 if the establishment reports high competitive pressure $(0.414,0.492)$ \\
\hline Wage level & Total wage bill per employee on June $30^{\text {th }}$ in Euro $(2004,1082)$ \\
\hline Works council share & $\begin{array}{l}\text { Share of establishments with a works council in the year } 2009 \text { calculated for } 41 \text { industrial groups } \\
\text { in } 16 \text { federal states }(0.260,0.202) \text {. }\end{array}$ \\
\hline Industry dummies & 12 industry dummies are included. \\
\hline Region dummies & 15 federal state dummies are included. \\
\hline
\end{tabular}


Table 3: Determinants of Workplace Health Promotion

\begin{tabular}{|c|c|c|c|c|c|c|c|c|}
\hline \multirow[b]{2}{*}{ Explanatory Variables } & \multicolumn{2}{|c|}{$\begin{array}{c}(1) \\
\text { All Establishments }\end{array}$} & \multicolumn{2}{|c|}{$\begin{array}{c}(2) \\
\text { All Establishments }\end{array}$} & \multicolumn{2}{|c|}{$\begin{array}{c}\text { (3) } \\
\text { Establishments with } \\
\text { 21-100 Employees }\end{array}$} & \multicolumn{2}{|c|}{$\begin{array}{c}(4) \\
\text { Establishments with } \\
21-300 \text { Employees }\end{array}$} \\
\hline & Coefficient & $\begin{array}{c}\text { Marginal } \\
\text { Effect }\end{array}$ & Coefficient & $\begin{array}{l}\text { Marginal } \\
\text { Effect }\end{array}$ & Coefficient & $\begin{array}{l}\text { Marginal } \\
\text { Effect }\end{array}$ & Coefficient & $\begin{array}{l}\text { Marginal } \\
\text { Effect }\end{array}$ \\
\hline Works council & $\begin{array}{c}0.331 \\
(6.35) * * *\end{array}$ & 0.094 & $\begin{array}{c}0.346 \\
(5.86) * * *\end{array}$ & 0.099 & $\begin{array}{c}0.323 \\
(4.52) * * *\end{array}$ & 0.109 & $\begin{array}{c}0.308 \\
(5.01)^{* * *}\end{array}$ & 0.093 \\
\hline Other representation & $\begin{array}{c}0.389 \\
(7.62) * * *\end{array}$ & 0.111 & $\begin{array}{c}0.387 \\
(6.97) * * *\end{array}$ & 0.110 & $\begin{array}{c}0.367 \\
(4.74) * * *\end{array}$ & 0.124 & $\begin{array}{c}0.315 \\
(4.54) * * *\end{array}$ & 0.095 \\
\hline Collective bargaining & $\begin{array}{c}0.099 \\
(2.64)^{* *}\end{array}$ & 0.028 & $\begin{array}{c}0.077 \\
(1.87)^{*}\end{array}$ & 0.022 & $\begin{array}{c}0.126 \\
(2.09)^{* *}\end{array}$ & 0.043 & $\begin{array}{c}0.121 \\
(2.27)^{* *}\end{array}$ & 0.037 \\
\hline $\operatorname{Ln}($ size $)$ & $\begin{array}{c}0.333 \\
(17.44) * * *\end{array}$ & 0.095 & $\begin{array}{c}0.333 \\
(15.71) * * *\end{array}$ & 0.095 & $\begin{array}{c}0.254 \\
(4.17) * * *\end{array}$ & 0.087 & $\begin{array}{c}0.300 \\
(8.11)^{* * *}\end{array}$ & 0.091 \\
\hline University degree & $\begin{array}{l}0.004 \\
(0.03)\end{array}$ & 0.001 & $\begin{array}{l}-0.149 \\
(0.99)\end{array}$ & -0.042 & $\begin{array}{l}-0.075 \\
(0.37)\end{array}$ & -0.025 & $\begin{array}{l}-0.026 \\
(0.14)\end{array}$ & -0.008 \\
\hline Skilled employees & $\begin{array}{l}-0.027 \\
(0.36)\end{array}$ & -0.008 & $\begin{array}{l}-0.013 \\
(0.16)\end{array}$ & -0.004 & $\begin{array}{l}-0.024 \\
(0.20)\end{array}$ & -0.008 & $\begin{array}{l}0.030 \\
(0.29)\end{array}$ & 0.009 \\
\hline Apprentices & $\begin{array}{c}1.222 \\
(4.91)^{* * *}\end{array}$ & 0.348 & $\begin{array}{c}1.615 \\
(5.77)^{* * *}\end{array}$ & 0.461 & $\begin{array}{c}2.136 \\
(4.49)^{* * *}\end{array}$ & 0.721 & $\begin{array}{c}2.161 \\
(5.03)^{* * *}\end{array}$ & 0.654 \\
\hline Women & $\begin{array}{l}0.084 \\
(1.07)\end{array}$ & 0.024 & $\begin{array}{l}0.077 \\
(0.87)\end{array}$ & 0.022 & $\begin{array}{l}0.169 \\
(1.28)\end{array}$ & 0.057 & $\begin{array}{l}0.185 \\
(1.54)\end{array}$ & 0.056 \\
\hline Part-time employees & $\begin{array}{l}-0.044 \\
(0.44)\end{array}$ & -0.013 & $\begin{array}{l}0.061 \\
(0.54)\end{array}$ & 0.017 & $\begin{array}{l}0.099 \\
(0.58)\end{array}$ & 0.033 & $\begin{array}{l}0.005 \\
(0.03)\end{array}$ & 0.001 \\
\hline Blue-collar workers & $\begin{array}{c}0.450 \\
(3.64)^{* * *}\end{array}$ & 0.128 & $\begin{array}{c}0.389 \\
(2.77)^{* * *}\end{array}$ & 0.111 & $\begin{array}{c}0.843 \\
(3.41)^{* * *}\end{array}$ & 0.285 & $\begin{array}{c}0.743 \\
(3.25)^{* * *}\end{array}$ & 0.225 \\
\hline Temporary agency & $\begin{array}{c}0.452 \\
(2.02)^{* *}\end{array}$ & 0.129 & $\begin{array}{l}0.342 \\
(1.42)\end{array}$ & 0.098 & $\begin{array}{c}0.635 \\
(1.96)^{*}\end{array}$ & 0.215 & $\begin{array}{l}0.340 \\
(1.16)\end{array}$ & 0.103 \\
\hline Weekly hours & $\begin{array}{l}-0.011 \\
(1.13)\end{array}$ & -0.003 & $\begin{array}{l}-0.005 \\
(0.47)\end{array}$ & -0.001 & $\begin{array}{l}-0.010 \\
(0.61)\end{array}$ & -0.003 & $\begin{array}{l}-0.015 \\
(1.03)\end{array}$ & -0.005 \\
\hline Flextime & $\begin{array}{c}0.259 \\
(7.37)^{* * *}\end{array}$ & 0.074 & $\begin{array}{c}0.246 \\
(6.43)^{* * *}\end{array}$ & 0.070 & $\begin{array}{c}0.268 \\
(4.83)^{* * *}\end{array}$ & 0.091 & $\begin{array}{c}0.260 \\
(5.37)^{* * *}\end{array}$ & 0.079 \\
\hline Shift work & $\begin{array}{c}0.233 \\
(5.49) * * *\end{array}$ & 0.066 & $\begin{array}{c}0.208 \\
(4.46) * * *\end{array}$ & 0.059 & $\begin{array}{c}0.293 \\
(4.73) * * *\end{array}$ & 0.099 & $\begin{array}{c}0.302 \\
(5.48) * * *\end{array}$ & 0.091 \\
\hline Sunday work & $\begin{array}{l}-0.088 \\
(1.72)^{*}\end{array}$ & -0.025 & $\begin{array}{l}-0.093 \\
(1.63)\end{array}$ & -0.026 & $\begin{array}{c}-0.258 \\
(3.06)^{* * *}\end{array}$ & -0.087 & $\begin{array}{c}-0.194 \\
(2.73)^{* * *}\end{array}$ & -0.059 \\
\hline Satisfactory technology & $\begin{array}{c}0.217 \\
(2.32)^{* *}\end{array}$ & 0.062 & $\begin{array}{c}0.210 \\
(2.06) * *\end{array}$ & 0.060 & $\begin{array}{c}0.242 \\
(1.75)^{*}\end{array}$ & 0.082 & $\begin{array}{c}0.285 \\
(2.26)^{* *}\end{array}$ & 0.086 \\
\hline Modern technology & $\begin{array}{c}0.244 \\
(2.64)^{* *}\end{array}$ & 0.069 & $\begin{array}{c}0.243 \\
(2.41)^{* *}\end{array}$ & 0.069 & $\begin{array}{c}0.252 \\
(1.86)^{*}\end{array}$ & 0.085 & $\begin{array}{c}0.350 \\
(2.82)^{* * *}\end{array}$ & 0.106 \\
\hline Latest technology & $\begin{array}{c}0.380 \\
(3.89)^{* * *}\end{array}$ & 0.108 & $\begin{array}{c}0.366 \\
(3.44)^{* * *}\end{array}$ & 0.104 & $\begin{array}{c}0.364 \\
(2.51)^{* *}\end{array}$ & 0.123 & $\begin{array}{c}0.474 \\
(3.59)^{* * *}\end{array}$ & 0.143 \\
\hline
\end{tabular}




\begin{tabular}{|c|c|c|c|c|c|c|c|c|}
\hline Innovation & $\begin{array}{c}0.302 \\
(8.95)^{* * *}\end{array}$ & 0.086 & $\begin{array}{c}0.317 \\
(8.57)^{* * * *}\end{array}$ & 0.091 & $\begin{array}{c}0.236 \\
(4.43)^{* * *}\end{array}$ & 0.080 & $\begin{array}{c}0.247 \\
(5.18) * * *\end{array}$ & 0.075 \\
\hline Limited liability & $\begin{array}{c}0.094 \\
(2.15)^{* *}\end{array}$ & 0.027 & $\begin{array}{l}0.070 \\
(1.45)\end{array}$ & 0.020 & $\begin{array}{l}0.054 \\
(0.66)\end{array}$ & 0.018 & $\begin{array}{l}0.081 \\
(1.05)\end{array}$ & 0.024 \\
\hline Single-site & $\begin{array}{c}-0.136 \\
(3.07) * * *\end{array}$ & -0.039 & $\begin{array}{c}-0.140 \\
(2.79) * * *\end{array}$ & -0.040 & $\begin{array}{l}-0.106 \\
(1.65)^{*}\end{array}$ & -0.036 & $\begin{array}{c}-0.114 \\
(2.09)^{* *}\end{array}$ & -0.035 \\
\hline Foreign owner & $\begin{array}{l}0.011 \\
(0.16)\end{array}$ & 0.003 & $\begin{array}{l}0.013 \\
(0.16)\end{array}$ & 0.004 & $\begin{array}{l}-0.012 \\
(0.11)\end{array}$ & -0.004 & $\begin{array}{l}0.053 \\
(0.61)\end{array}$ & 0.016 \\
\hline Owner-manager & $\begin{array}{c}-0.184 \\
(3.92)^{* * *}\end{array}$ & -0.052 & $\begin{array}{c}-0.209 \\
(3.97)^{* * *}\end{array}$ & -0.060 & $\begin{array}{l}-0.132 \\
(1.95)^{*}\end{array}$ & -0.045 & $\begin{array}{c}-0.147 \\
(2.51)^{* *}\end{array}$ & -0.044 \\
\hline Minor pressure & $\begin{array}{l}-0.059 \\
(0.71)\end{array}$ & -0.017 & $\begin{array}{l}-0.089 \\
(0.98)\end{array}$ & -0.025 & $\begin{array}{l}-0.208 \\
(1.42)\end{array}$ & 0.070 & $\begin{array}{l}-0.153 \\
(1.13)\end{array}$ & -0.046 \\
\hline Medium pressure & $\begin{array}{l}-0.067 \\
(0.89)\end{array}$ & -0.019 & $\begin{array}{l}-0.076 \\
(0.92)\end{array}$ & -0.022 & $\begin{array}{l}-0.172 \\
(1.30)\end{array}$ & -0.058 & $\begin{array}{l}-0.132 \\
(1.08)\end{array}$ & -0.040 \\
\hline High pressure & $\begin{array}{l}-0.077 \\
(1.02)\end{array}$ & -0.022 & $\begin{array}{l}-0.098 \\
(1.17)\end{array}$ & -0.028 & $\begin{array}{l}-0.183 \\
(1.38)\end{array}$ & -0.062 & $\begin{array}{l}-0.118 \\
(0.96)\end{array}$ & -0.036 \\
\hline Wage level & --- & --- & $\begin{array}{c}0.0001 \\
(2.58)^{* *}\end{array}$ & 0.0001 & & & & \\
\hline $\begin{array}{l}\text { Industry and region } \\
\text { dummies }\end{array}$ & \multicolumn{2}{|c|}{ Included } & \multicolumn{2}{|c|}{ Included } & \multicolumn{2}{|c|}{ Included } & \multicolumn{2}{|c|}{ Included } \\
\hline Pseudo $\mathrm{R}^{2}$ & \multicolumn{2}{|c|}{0.271} & \multicolumn{2}{|c|}{0.270} & \multicolumn{2}{|c|}{0.116} & \multicolumn{2}{|c|}{0.153} \\
\hline $\mathrm{N}$ & \multicolumn{2}{|c|}{8215} & \multicolumn{2}{|c|}{6895} & \multicolumn{2}{|c|}{2870} & \multicolumn{2}{|c|}{3966} \\
\hline
\end{tabular}

Dependent variable: Workplace health promotion. Method: Probit. Marginal effects of dummy variables are evaluated for a discrete change from 0 to 1 . Marginal effects other than dummy variables are evaluated at the mean values. Z-statistics in parentheses are based on robust standard errors. *** Statistically significant at the $1 \%$ level; ** at the 5\% level; * at the $10 \%$ level. 
Table 4: Separate Regressions

\begin{tabular}{|c|c|c|c|c|}
\hline Split Variable & \multicolumn{4}{|c|}{ Collective Bargaining } \\
\hline \multirow{2}{*}{ Explanatory Variable } & \multicolumn{2}{|c|}{ No } & \multicolumn{2}{|c|}{ Yes } \\
\hline & Coefficient & Marginal Effect & Coefficient & Marginal Effect \\
\hline Works council & $\begin{array}{c}0.293 \\
(3.88)^{* * * *}\end{array}$ & 0.089 & $\begin{array}{c}0.389 \\
(4.92)^{* * * *}\end{array}$ & 0.098 \\
\hline Number of observations; Pseudo $\mathrm{R}^{2}$ & \multicolumn{2}{|c|}{$4931 ; 0.223$} & \multicolumn{2}{|c|}{$3284 ; 0.318$} \\
\hline Equality of coefficients & \multicolumn{4}{|c|}{0.38} \\
\hline Split Variable & \multicolumn{4}{|c|}{ Other Representation } \\
\hline \multirow{2}{*}{ Explanatory Variable } & \multicolumn{2}{|c|}{ No } & \multicolumn{2}{|c|}{ Yes } \\
\hline & Coefficient & Marginal Effect & Coefficient & Marginal Effect \\
\hline Works council & $\begin{array}{c}0.292 \\
(5.35)^{* * *}\end{array}$ & 0.083 & $\begin{array}{c}0.588 \\
(2.98) * * *\end{array}$ & 0.164 \\
\hline Number of observations; Pseudo $\mathrm{R}^{2}$ & \multicolumn{2}{|c|}{$7214 ; 0.275$} & \multicolumn{2}{|c|}{$1001 ; 0.214$} \\
\hline Equality of coefficients & \multicolumn{4}{|c|}{0.15} \\
\hline Split Variable & \multicolumn{4}{|c|}{ Single-Site } \\
\hline \multirow{2}{*}{ Explanatory Variable } & \multicolumn{2}{|c|}{ No } & \multicolumn{2}{|c|}{ Yes } \\
\hline & Coefficient & Marginal Effect & Coefficient & Marginal Effect \\
\hline Works council & $\begin{array}{c}0.497 \\
(5.86)^{* * *}\end{array}$ & 0.113 & $\begin{array}{c}0.209 \\
(3.09)^{* * * *}\end{array}$ & 0.063 \\
\hline Number of observations; Pseudo $\mathrm{R}^{2}$ & \multicolumn{2}{|c|}{$2146 ; 0.290$} & \multicolumn{2}{|c|}{$6069 ; 0.224$} \\
\hline Equality of coefficients & \multicolumn{4}{|c|}{$0.008 * * *$} \\
\hline Split Variable & \multicolumn{4}{|c|}{ Foreign Owner } \\
\hline \multirow{2}{*}{ Explanatory Variable } & \multicolumn{2}{|c|}{ No } & \multicolumn{2}{|c|}{ Yes } \\
\hline & Coefficient & Marginal Effect & Coefficient & Marginal Effect \\
\hline Works council & $\begin{array}{c}0.312 \\
(5.68)^{* * * *}\end{array}$ & 0.091 & $\begin{array}{c}0.695 \\
(3.61)^{* * * *}\end{array}$ & 0.122 \\
\hline Number of observations; Pseudo $\mathrm{R}^{2}$ & \multicolumn{2}{|c|}{$7587 ; 0.257$} & \multicolumn{2}{|c|}{$628 ; 0.438$} \\
\hline Equality of coefficients & \multicolumn{4}{|c|}{$0.06^{*}$} \\
\hline Split Variable & \multicolumn{4}{|c|}{ Owner-Manager } \\
\hline \multirow{2}{*}{ Explanatory Variable } & & & & es \\
\hline & Coefficient & Marginal Effect & Coefficient & Marginal Effect \\
\hline Works council & $\begin{array}{c}0.298 \\
(3.77)^{* * * *}\end{array}$ & 0.068 & $\begin{array}{c}0.339 \\
(4.74)^{* * * *}\end{array}$ & 0.104 \\
\hline Number of observations; Pseudo $\mathrm{R}^{2}$ & & 251 & & 0.208 \\
\hline Equality of coefficients & & 0. & & \\
\hline Split Variable & & Shift & & \\
\hline$\Gamma$ & & & & es \\
\hline Explanatory Varlable & Coefficient & Marginal Effect & Coefficient & Marginal Effect \\
\hline Works council & $\begin{array}{c}0.335 \\
(4.73)^{* * * *}\end{array}$ & 0.083 & $\begin{array}{c}0.344 \\
(4.16)^{* * *}\end{array}$ & 0.083 \\
\hline
\end{tabular}




\begin{tabular}{|c|c|c|c|c|}
\hline Number of observations; Pseudo $\mathrm{R}^{2}$ & \multicolumn{2}{|c|}{$5165 ; 0.193$} & \multicolumn{2}{|c|}{$3050 ; 0.252$} \\
\hline Equality of coefficients & \multicolumn{4}{|c|}{0.93} \\
\hline Split Variable & \multicolumn{4}{|c|}{ Industry } \\
\hline \multirow{2}{*}{ Explanatory Variable } & \multicolumn{2}{|c|}{ Manufacturing } & \multicolumn{2}{|c|}{ Service } \\
\hline & Coefficient & Marginal Effect & Coefficient & Marginal Effect \\
\hline Works council & $\begin{array}{c}0.306 \\
(3.51)^{* * * *}\end{array}$ & 0.081 & $\begin{array}{c}0.343 \\
(4.73) * * *\end{array}$ & 0.099 \\
\hline Number of observations; Pseudo $\mathrm{R}^{2}$ & \multicolumn{2}{|c|}{$3112 ; 0.295$} & \multicolumn{2}{|c|}{$4369 ; 0.260$} \\
\hline Equality of coefficients & \multicolumn{4}{|c|}{0.74} \\
\hline Split Variable & \multicolumn{4}{|c|}{ West Germany / East Germany } \\
\hline \multirow{2}{*}{ Explanatory Variable } & \multicolumn{2}{|c|}{ West Germany } & \multicolumn{2}{|c|}{ East Germany } \\
\hline & Coefficient & Marginal Effect & Coefficient & Marginal Effect \\
\hline Works council & \multirow{2}{*}{$\begin{array}{c}0.394 \\
(6.04)^{* * *}\end{array}$} & \multirow[t]{2}{*}{0.109} & 0.193 & \multirow[t]{2}{*}{0.057} \\
\hline & & & $(2.19)^{* *}$ & \\
\hline Number of observations; Pseudo $\mathrm{R}^{2}$ & \multicolumn{2}{|c|}{$4983 ; 0.292$} & \multicolumn{2}{|c|}{$3232 ; 0.249$} \\
\hline Equality of coefficients & \multicolumn{4}{|c|}{$0.07 *$} \\
\hline Split Variable & \multicolumn{4}{|c|}{ Product Market Competition } \\
\hline \multirow{2}{*}{ Explanatory Variable } & \multicolumn{2}{|c|}{ No Competition } & \multicolumn{2}{|c|}{ Weak Competition } \\
\hline & Coefficient & Marginal Effect & Coefficient & Marginal Effect \\
\hline Works council & $\begin{array}{l}0.107 \\
(0.43)\end{array}$ & 0.029 & $\begin{array}{c}0.363 \\
(2.02)^{* *}\end{array}$ & 0.105 \\
\hline Number of observations; Pseudo $\mathrm{R}^{2}$ & \multicolumn{2}{|c|}{$420 ; 0.312$} & \multicolumn{2}{|c|}{$978 ; 0.260$} \\
\hline \multirow[t]{3}{*}{ Equality of coefficients } & \multicolumn{2}{|c|}{0.37} & \multicolumn{2}{|c|}{0.84} \\
\hline & \multicolumn{2}{|c|}{ Some Competition } & \multicolumn{2}{|c|}{ Strong Competition } \\
\hline & Coefficient & Marginal Effect & Coefficient & Marginal Effect \\
\hline Works council & $\begin{array}{c}0.262 \\
(3.14)^{* * * *}\end{array}$ & 0.075 & $\begin{array}{c}0.376 \\
(4.78) * * *\end{array}$ & 0.102 \\
\hline Number of observations; Pseudo $\mathrm{R}^{2}$ & \multicolumn{2}{|c|}{$3419 ; 0.270$} & \multicolumn{2}{|c|}{$3397 ; 0.296$} \\
\hline Equality of coefficients & \multicolumn{2}{|c|}{0.36} & & 45 \\
\hline
\end{tabular}

Dependent variable: Workplace health promotion. Method: Probit. Results on the control variables are suppressed to save space. The marginal effects of the works council dummy are evaluated for a discrete change from 0 to 1 . Z-statistics for the coefficients in parentheses are based on robust standard errors. For the test of equality of coefficients, p-values are shown. For the competition variables, each competition regime is tested against the other three regimes. *** Statistically significant at the $1 \%$ level; ** at the $5 \%$ level. 
Table 5: Measures of Workplace Health Promotion

\begin{tabular}{|c|c|c|c|c|}
\hline \multirow{2}{*}{$\begin{array}{l}\text { Dependent Variables } \\
\text { Explanatory Variable }\end{array}$} & \multicolumn{2}{|c|}{ Sickness Absence Analysis } & \multicolumn{2}{|c|}{ Employee Surveys } \\
\hline & Coefficient & Marginal Effect & Coefficient & Marginal Effect \\
\hline Works Council & $\begin{array}{c}0.280 \\
(5.66)^{* * *} \\
\end{array}$ & 0.070 & $\begin{array}{c}0.226 \\
(4.58) * * * \\
\end{array}$ & 0.060 \\
\hline \multirow[t]{3}{*}{ Number of observations; Pseudo $\mathrm{R}^{2}$} & \multicolumn{2}{|c|}{$8215 ; 0.299$} & \multicolumn{2}{|c|}{$8215 ; 0.135$} \\
\hline & \multicolumn{2}{|c|}{ Health Circles } & \multicolumn{2}{|c|}{ In-House Activities } \\
\hline & Coefficient & Marginal Effect & Coefficient & Marginal Effect \\
\hline Works Council & $\begin{array}{c}0.367 \\
(6.51)^{* * *}\end{array}$ & 0.063 & $\begin{array}{c}0.277 \\
(5.35)^{* * *}\end{array}$ & 0.058 \\
\hline Number of observations; Pseudo $\mathrm{R}^{2}$ & \multicolumn{2}{|c|}{$8215 ; 0.187$} & \multicolumn{2}{|c|}{$8215 ; 0.252$} \\
\hline Dependent Variables & \multicolumn{2}{|c|}{ Health Training } & \multicolumn{2}{|c|}{ Financial Support } \\
\hline Explanatory Variable & Coefficient & Marginal Effect & Coefficient & Marginal Effect \\
\hline Works Council & $\begin{array}{c}0.237 \\
(4.40)^{* * *}\end{array}$ & 0.043 & $\begin{array}{c}0.123 \\
(2.05)^{* *}\end{array}$ & 0.018 \\
\hline Number of observations; Pseudo $\mathrm{R}^{2}$ & \multicolumn{2}{|c|}{$8215 ; 0.256$} & \multicolumn{2}{|c|}{$8215 ; 0.172$} \\
\hline Dependent Variable & \multicolumn{2}{|c|}{ Cross-Company Network } & \multicolumn{2}{|c|}{ Other Measures } \\
\hline Explanatory Variable & Coefficient & Marginal Effect & Coefficient & Marginal Effect \\
\hline Works Council & $\begin{array}{c}0.266 \\
(4.65)^{* * *}\end{array}$ & 0.041 & $\begin{array}{c}0.109 \\
(1.73)^{*}\end{array}$ & 0.016 \\
\hline Number of observations; Pseudo $\mathrm{R}^{2}$ & \multicolumn{2}{|c|}{$8215 ; 0.262$} & \multicolumn{2}{|c|}{$8215 ; 0.069$} \\
\hline
\end{tabular}

Method: Probit. Results on the control variables are suppressed to save space. The marginal effects of the works council dummy are evaluated for a discrete change from 0 to 1 . Z-statistics for the coefficients in parentheses are based on robust standard errors. *** Statistically significant at the $1 \%$ level; ** at the $5 \%$ level; * at the $10 \%$ level. 
Table 6: The Issue of Endogeneity

\begin{tabular}{|l|c|c|c|c|}
\hline \multirow{2}{*}{ Explanatory Variables } & Workplace Health Promotion & \multicolumn{2}{c|}{ Works Council } \\
\cline { 2 - 5 } & Coefficient & $\begin{array}{c}\text { Marginal } \\
\text { Effect }\end{array}$ & Coefficient & $\begin{array}{c}\text { Marginal } \\
\text { Effect }\end{array}$ \\
\hline Works council & $\begin{array}{c}0.520 \\
(4.39)^{* * *}\end{array}$ & 0.284 & --- & 0.522 \\
\hline Works council share & --- & --- & 1.377 \\
$(9.08)^{* * *}$ & \\
\hline N & & & 8215 & \\
\hline Rho & & \multicolumn{2}{|c|}{-0.127} \\
\hline$\chi^{2}$ (Wald test of exogeneity) & \multicolumn{3}{|c|}{$3.098^{*}$} \\
\hline
\end{tabular}

Method: Recursive bivariate probit. Results on the control variables are suppressed to save space. The marginal effect of the works council dummy is evaluated for a discrete change from 0 to 1 . The marginal effect of the instrument is evaluated at the mean value. Z-statistics in parentheses are based on robust standard errors. Rho is the correlation between the error terms in equations (3) and (4). *** Statistically significant at the $1 \%$ level; * at the $10 \%$ level. 


\section{Endnotes}

${ }^{1}$ Jirjahn (2018) provides evidence that works councils can indeed shape employer attitudes toward HRM practices.

2 A similar reasoning applies to family friendly work practices (Aghion and Hermalin 1990, Heywood and Jirjahn 2009).

${ }^{3}$ The IAB assures the interviewees of an absolutely anonymous treatment of the data. Thus, interviewees have no incentive for strategic answers.

${ }^{4}$ The full results are available from the authors.

${ }^{5}$ Substantial increases in the estimated effects are not unusual in studies accounting for endogeneity. For example, this phenomenon has been observed in studies on the returns to schooling (Card 1995, Ichino and Winter-Ebmer 1999). 